\title{
Deset istina o proceduri za države s prekomjernim proračunskim deficitom
}

\author{
ANTO BAJO Institut za javne financije \\ DAVOR GALINEC Hrvatska narodna banka ${ }^{\mathrm{I}}$
}

Paktom o stabilnosti i rastu (SGP) i kriterijima iz Maastrichta utvrđena su ograničenja rasta javnog duga i proračunskog deficita, kao i procedura za države s prekomjernim proračunskim deficitom (engl. Excessive Deficit Procedure - EDP) koje ne zadovoljavaju fiskalne kriterije iz Maastrichta ${ }^{2}$. Europska komisija vjerojatno će primijeniti EDP i na Hrvatsku zbog više razine proračunskog deficita od referentne vrijednosti, ali i rastućeg javnog duga. Pritom Europska komisija ne preuzima kontrolu nad izvršenjem proračuna države članice u smislu da izravno predlaže mjere ni na prihodnoj, ni na rashodnoj strani proračuna. Europska komisija prati ostvarenje ciljeva zadanih Preporukom za izlazak iz situacije prekomjernog deficita, a zemlja članica određuje kombinaciju mjera u ostvarivanju ciljeva utvrdenih Preporukom.

\begin{abstract}
I. Postupak za države s prekomjernim proračunskim deficitom uvodi se zbog stabilizacije državnỉh financija EU-a i zemalja članica. Prema kriterijima iz Maastrichta, proračunski deficit konsolidirane opće države zemlje članice ne smije biti veći od 3\% BDP-a, a dug opće države 60\% BDP-a (prema ESA 95 definicijama). U slučaju prelaska referentnih veličina aktivira se EDP, čiji je glavni cilj osigurati da se države članice pridržavaju kriterija iz Maastrichta. Prosječni proračunski deficit EU 27 od 1997. do 2008. manji je od 3\% BDP-a, naredne dvije krizne godine raste na više od 6\%, da bi se u 2011. i 2012. smanjio na 4\%. Europska komisija očekuje i daljnja smanjenja deficita na oko 3,2\% BDP-a u 20I4. (grafikon I). Od 2000. do 2008. prosječan dug opće države u EU-u iznosio je oko 60\% BDP-a, da bi u narednim godinama rastao i 20I2. dosegao 87\% BDP-a. Zemlje članice nastavljaju se zaduživati, zbog čega se 20I4. u EU-u očekuje prosječan rast duga na 9I\% BDP-a (grafikon 2).
\end{abstract}

2. EDP traje tri godine, a prema preporukama Europske komisije šest mjeseci je rok za poduzimanje radnji za smanjenje deficita. Ukoliko država članica potpadne pod EDP, usklađivanja deficita i javnog duga traju minimalno tri godine. Postoje i izuzeci, pa je Bugarska bila u EDP-u dvije godine s primarnim ciljem smanjenja proračunskog deficita jer je javni dug nizak - ispod referentne vrijednosti za primjenu

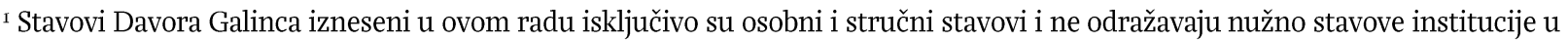
kojoj je zaposlen, niti je na bilo koji način obvezuje.

${ }^{2}$ Postupak za države s prekomjernim deficitom temelji se na odredbama Pakta o stabilnosti i rastu, kriterijima iz Maastrichta, Uredbi Vijeća (EZ) I467/97 o ubrzanju i pojašnjenju provedbe postupka te Uredbi Vijeća (EZ) 479/2009 o primjeni Protokola 0 postupku prekomjernog proračunskog deficita. 
EDP-a. Ukoliko se ciljevi ne ostvaruju i ne poduzimaju odgovarajuće mjere, EDP se može i produljiti. Tako je u Mađarskoj izlazak iz EDP-a trajao devet godina (od 2004. do 2013.). Europska komisija formalno uključuje državu članicu u EDP, donosi preporuke i državi određuje rok od najviše šest mjeseci za poduzimanje radnji za smanjenje deficita i javnog duga. Utvrdi li Europska komisija da takve radnje nisu poduzete ili su rezultati poduzetih radnji neučinkoviti, onda kao vrstu pritiska koristi javnu objavu preporuka te uvođenje kazni (kao krajnju mjeru).

3. Premda je EDP primarno usmjeren na proračunski deficit, jednako se primjenjuje i na javni dug. Država članica koja se nalazi u EDP-u mora tijekom trogodišnjeg razdoblja smanjiti jaz između postojeće razine javnog duga i referentne razine od 60\% BDP-a za prosječno I/20 godišnje. Uz pretpostavku javnog duga, primjerice od 70\% BDP-a, Hrvatska bi tijekom trogodišnjeg razdoblja trebala smanjiti iznos prekomjernog javnog duga od IO\% BDP-a za 3/20, odnosno za 1,5\% BDP-a. Tako bi ukupni javni dug nakon tri godine trebao biti smanjen sa 70 na "prihvatljivu" razinu od 68,5\% BDP-a. Istekom dvadesete godine od primjene konzistentnih mjera fiskalne prilagodbe, mogla bi se doseći referentna vrijednost od 60\% udjela javnog duga u BDP-u (uz pretpostavku da stopa rasta novog zaduživanja ne bude veća od stope rasta BDP-a, umanjeno za I/20 iznosa prekomjernog duga).

4. Predviđene kazne za nepridržavanja EDP-a su novčane u postotku BDP-a ili ograničenja pristupa sredstvima strukturnih fondova. Kazne za zemlje članice Eurozone predviđene su u obliku depozita i utvrđuju se u iznosu od o,2 do o,5\% BDP-a dotične zemlje (sukladno odredbama tzv. 6 pack seta pravnih akata EU-a). Ostale članice EU-a mogu biti privremeno uskraćene za povlačenja sredstava iz fondova EU-a. Nakon ispunjavanja uvjeta iz EDP-a, zemljama se vraća uplaćeni depozit i omogućava pristup fondovima.

5. Fiskalna transparentnost je značajna. Ukoliko se država članica ne pridržava preporuka u okviru EDP-a i ne dostavlja vjerodostojne statističke podatke o proračunskom deficitu i javnom dugu iskazane na ESA 95 načelima (dvaput godišnje, krajem ožujka i krajem rujna), Eurostat (statistički ured Europske komisije) može javno iskazati tzv. "rezervacije na kvalitetu podataka" i korigirati pokazatelje deficita i duga koje je u EDP izvješću iskazala država članica. Eurostat o obavljenim korekcijama izvještava državu članicu i predsjednika Ekonomskog i financijskog komiteta (EFC) i to u roku od najviše tri dana uoči objave korigiranih pokazatelja na mrežnim stranicama Eurostata. U slučaju da Eurostat javno iskaže "rezervaciju na kvalitetu podataka3", sljedeći korak je izrada plana za poboljšanje EDP statistike u državi članici za koju je iskazana rezervacija (što uključuje i mjere za jačanje ljudskih potencijala u nacionalnim statističkim zavodima koji sastavljaju EDP izvješća) i organiziranje Metodološkog posjeta državi članici s ciljem da se problem riješi i povuče iskazana rezervacija. Izvješćem o kvaliteti fiskalnih podataka Eurostat redovito izvještava EFC i Europski parlament o kvaliteti EDP statistika koje dostavlja država članica4.

6. EDP se temelji na metodologiji ESA 95, koja se razlikuje od GFS-a Međunarodnog monetarnog fonda po kojem je Hrvatska vodila državne financije. Po ESA 95, proračunski deficit i javni dug je veći zbog šireg obuhvata jedinica sektora opće države i vrsta financijskih transakcija/instrumenta koji ulaze u izračun. Statistika državnih financija (GFS 200I) MMF-a temelji se na pokazateljima državnih financija izračunatih korištenjem podataka nacionalnih ministarstava financija (financijska izvješća proračunskih korisnika i transakcije državne riznice). ESA95 koncept izračuna deficita $\mathrm{i}$ javnog duga podrazumijeva korištenje financijskih izvješća svih jedinica statistički svrstanih u sektor države.

Na prijedlog Europske Komisije, u sektor opće države uvrštavaju se i poduzeća u vlasništvu središnje države ili jedinica lokalne samouprave koja stvaraju gubitke i kumuliraju dugove. Tako gubici i obveze određenih državnih poduzeća ulaze u obuhvat proračunskog deficita i duga opće države, a uključuju se

3 Grčka od 2005. do 2009. je dobar primjer javne rezervacije kojom Eurostat iskazuje sumnje u kvalitetu EDP podataka (dostupno na: http://eur-lex.europa.eu/LexUriServ/LexUriServ.do?uri=SPLIT_COM:2OIo:OoOI(O4):FIN:EN:PDF)

${ }^{4}$ Izvješća o kvaliteti državnih financija dostupna su na:

http://epp.eurostat.ec.europa.eu/portal/page/portal/government_finance_statistics/publications/quality_reports 
i nefinancijske transakcije koje utječu na deficit i/ili dug (npr. jednostrani otpisi dugova države - kao vjerovnika - određenim kategorijama dužnika ili pretvaranje državnih potraživanja u vlasničke udjele i sl.).

U Hrvatskoj se, u dosadašnjim izračunima deficita i duga opće države prema GFS-u, obuhvat lokalne države odnosio samo na 53 "fiskalno najznačajnije" lokalne jedinice. Prema ESA 95 u obuhvat lokalne države uključuju se sve (576) jedinice lokalne samouprave. Pored toga, u dosadašnjim izračunima prema GFS-u, poslovanje Hrvatskog zavoda za zdravstveno osiguranje (HZZO) i Hrvatskog zavoda za mirovinsko osiguranje (HZMO) obavljalo se u sklopu državnog proračuna. Prema ESA 95, HZMO i HZZO su reklasificirani u poseban podsektor "Fondovi socijalne sigurnosti". Tako se transparentnije mogu pratiti financijski tijekovi između zavoda i središnje države.

7. Većina država članica EU-a ne ispunjava kriterije iz Maastrichta - 2012. je I6 država imalo višu razinu proračunskog deficita, a I4 država višu razinu javnog duga. Tijekom 2012. najveće proračunske deficite (tablica I) imale su Španjolska (Io,6\% BDP-a), Grčka (IO\% BDP-a), Irska (7,6\% BDP-a), Portugal (6,4\% BDP-a) te Cipar i Velika Britanija (po 6,3\% BDP-a). Tek je II država 20ı2. bilježilo deficite manje od 3\% BDP-a. Od 2009. do 2012. proračunski deficit EU 27 država članica je smanjen, ali je zato javni dug rastao s 74,6\% BDP-a u 2009. na 85,3\% BDP-a u 2012.

Najveći javni dug (osim Grčke) 20I2. bilježe Italija (I27\% BDP-a), Portugal (I23,6\% BDP-a) i Irska (II7,6\% BDP-a). Tek je I3 zemalja 20I2. imalo javni dug niži od 60\% BDP-a. To su sve nove članice EU-a (zemlje Središnje i Istočne Europe) i Švedska (tablica 2).

8. Od 27 zemalja članica njih 25 je dosad bilo u EDP-u. Jedino Estonija i Švedska nisu bile obuhvaćene EDP-om5. Odlukom Vijeća EU-a, sredinom 2012. su iz mehanizma EDP-a izašle Bugarska i Njemačka, a prije toga Luxemburg (2010.) i Finska (2OII.). Po završetku Europskog semestra 2013., iz EDP-a su izašle Italija, Mađarska, Litva, Latvija i Rumunjska, a nad Maltom je EDP ponovno pokrenut.

Trenutno se I6 država članica nalazi u EDP-u. Većina ih je u EDP ušla 2009., s izuzetkom Cipra i Danske (2010.) te Velike Britanije (2008.). Od svih država članica koje su ušle u EDP 2009., nakon tri godine (2012.) su izašle Italija, Rumunjska, Latvija i Litva. Belgiji je EDP produljen i na 20I3., a vjerojatno i dalje jer dosadašnje poduzete mjere nisu bile učinkovite. Isto tako, nakon proteka tri godine (u 20I2.), šest država (Nizozemska, Portugal, Slovenija, Poljska, Francuska i Španjolska) nisu u potpunosti uspjele ostvariti zadane ciljeve i preporuke, tako da im je trajanje EDP-a produljeno do 20I4. ili 2015. Mađarska je jedina članica koja je nakon punih devet godina (u 2013.) izašla iz EDP-a.

9. Zbog brojnih financijskih rizika, Hrvatska će vjerojatno ući u EDP. Hrvatska postupno usvaja statističke standarde i usklađuje statistiku državnih financija s Eurostatom. Državni zavod za statistiku (u suradnji s HNB-om, i Ministarstvom financija) priprema statistiku o kretanjima (prekomjernih) proračunskih deficita i javnog duga. Koncem rujna 20I3. Hrvatska će Eurostatu prvi puta u svojstvu države članice dostaviti podatke o proračunskom deficitu i dugu opće države u sklopu EDP notifikacije, a tijekom druge polovice listopada podaci će biti istovremeno javno objavljeni na mrežnim stranicama Eurostata i DZS-a. U Hrvatskoj su za sada javno dostupni podaci iskazani po GFS-u, prema kojem je proračunski deficit opće države od 2010. iznad 3\% BDP-a, a dug opće države u lipnju 2013. je na razini 53,7\% BDP-a.

Glavni je razlog ulaska u EDP visoki proračunski deficit. Međutim, zbog visokih potencijalnih obveza (aktivnih državnih jamstava) te izravnih obveza HBOR-a (koje jamči država - solidarno i neograni- čeno), i javni dug bi lako mogao biti predmetom EDP-a jer bi zbog šireg obuhvata po ESA 95 mogao prijeći referentnu razinu od 60\% BDP-a (tablica 3).

5 Zbog tek nedavnog ulaska u punopravno članstvo EU-a, Hrvatska formalno nije ni mogla ući u EDP. 
Postoji velika mogućnost da se zbog nepodmirivanja kreditnih obveza (osiguranih državnim jamstvima) Hrvatskim autocestama (HAC) aktiviraju državna jamstva. Ako se jamstva aktiviraju, HAC se reklasificira iz sektora javnih nefinancijskih društava u sektor središnje države, čime njegovi tekući gubici i obveze ulaze u obuhvat i povećavaju deficit i dug opće države.

Sličan je slučaj i Zagrebačkog holdinga (društva u Ioo\% vlasništvu Grada Zagreba). Ukoliko se postojeće obveze Holdinga saniraju transferima iz proračuna Grada Zagreba (uključujući operacije prodaje nekretnina i poduzeća u vlasništvu Holdinga Gradu Zagrebu), Holding će se reklasificirati iz sektora javnih nefinancijskih poduzeća u sektor lokalne države. Na taj način obveze Holdinga izravno prijete državnim financijama, povećanjem duga opće države.

Dodatni izvor rizika za rast deficita i duga opće države jesu i promjene $u$ Eurostatovom obuhvatu dužničkih instrumenata. Naime, Odlukom od 31. srpnja 2012. Eurostat je dopunio postojeću definiciju duga opće države prema kriterijima iz Maastrichta (referentna granica od 60\% ostaje ista). Eurostatova se odluka odnosi na uključivanje trgovačkih kredita u dva slučaja. U prvom slučaju, kada dobavljač proizvoda ili usluga u potpunosti i neopozivo prenese svoja potraživanja prema državnoj jedinici na financijsku instituciju (faktoring kompanija ili neka druga financijska institucija), uz pristanak države. Drugi se slučaj odnosi na restrukturiranje trgovačkih kredita, kada bilateralnim dogovorom između dobavljača i državne jedinice dođe do nastanka ili dopune ugovora kojim se mijenjaju karakteristike postojećeg trgovačkog kredita (tj. izvorno dogovorenog roka odgode plaćanja), način određivanja kamatne stope i/ili promjene roka dospijeća i/ili stvaranje otplatnog plana. U oba se slučaja iznosi originalnog trgovačkog kredita prenose na stavku kredita koja postaje sastavni dio obuhvata EDP duga opće države.

Na kraju ostaje pitanje hoće li EDP Hrvatskoj biti otvoren do kraja 2013. (temeljem rezultata EDP izvješća koje se dostavlja krajem rujna 2013.) ili sredinom 20I4., po završetku Europskog semestra.

Io. Europska komisija ne preuzima kontrolu proračuna Republike Hrvatske. Prilikom stupanja države članice u EDP, temeljem Članka I26(7) Sporazuma o funkcioniranju EU (TFEU), Europsko vijeće - na prijedlog Europske komisije - državi članici daje Preporuku za izlazak iz situacije prekomjernog deficita. U Preporuci su postavljeni ciljevi koji moraju biti ostvareni (npr. ako zemlja bilježi deficit od 5\% BDP-a u 2013., očekuje se smanjenje deficita na razinu nižu od 4\% BDP-a u 20I4. i nižu od 3\% u 2015.) i zahtjev da država članica sama izloži i primijeni paket mjera koje planira poduzeti radi smanjenja prekomjernog deficita za vrijeme trajanja EDP-a. Dakle, Europska komisija ne preuzima kontrolu nad izvršenjem proračuna države članice tako da izravno predlaže mjere, ni na prihodnoj ni na rashodnoj strani proračuna. Europska komisija prati ostvarenje ciljeva zadanih Preporukom, a zemlja članica određuje kombinaciju mjera koje vode ostvarenju ciljeva utvrđenih Preporukom. 


\section{Grafikon I.}

Prosječni javni dug EU27 od 1996. do 20I4. (\% BDP-a)

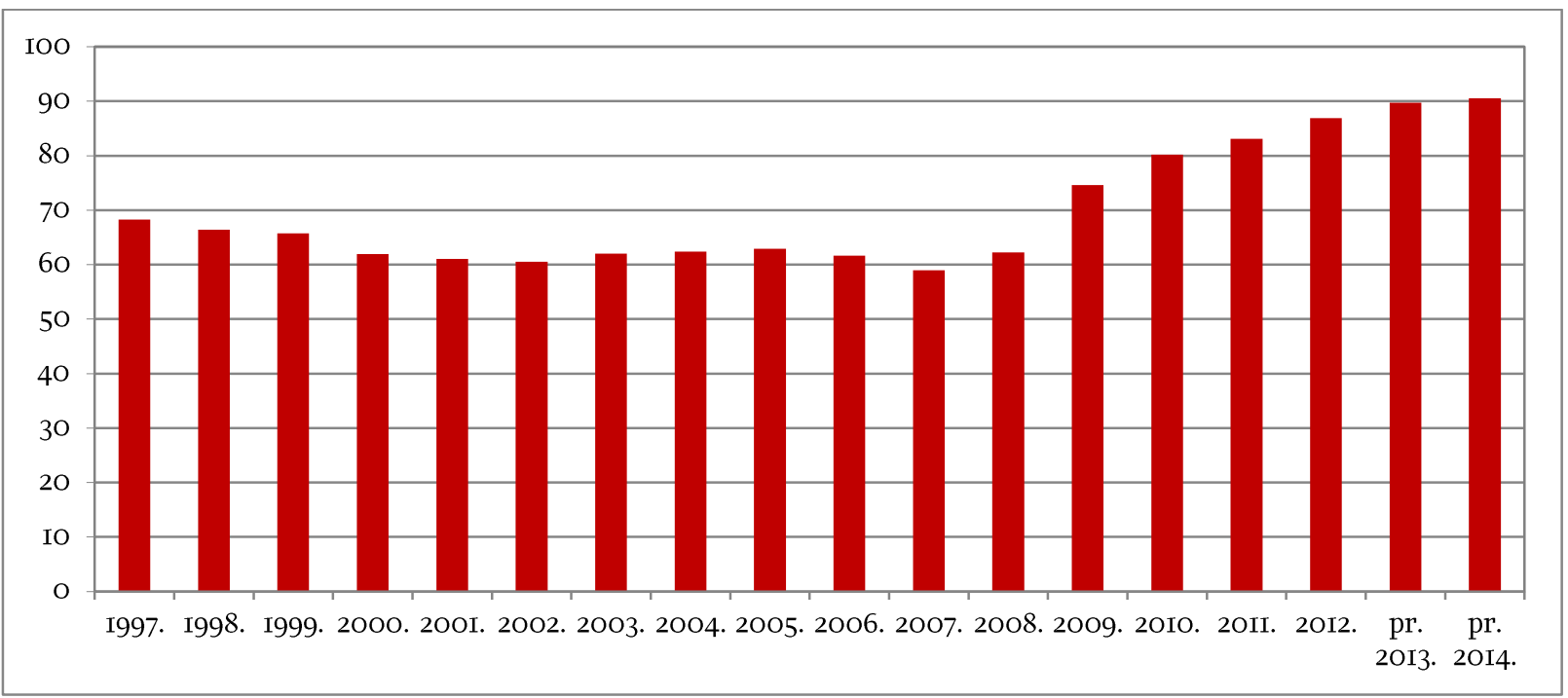

Napomena: projekcije za 20I3. i 2014.

Izvor: Eurostat, 20I3.

\section{Grafikon 2.}

Proračunski deficiti EU27 od 1996. do 20I4. (u \% BDP-a)

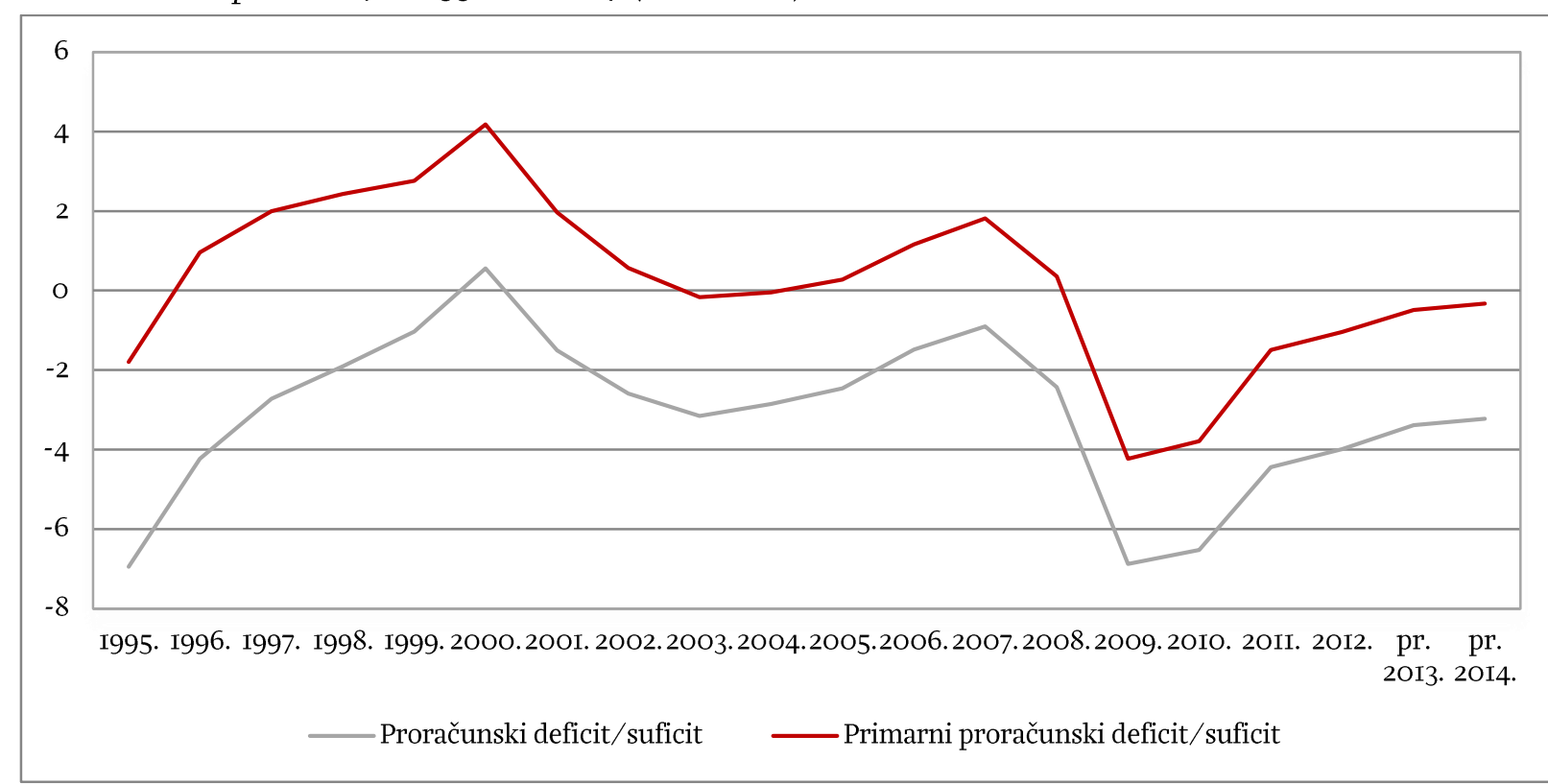

Napomena: projekcije za 20I3. i 2014.

Izvor: Eurostat, 2013. 
Tablica I.

Deficit proračuna opće države od 2007. do 2012. (u \% BDP-a)

\begin{tabular}{|c|c|c|c|c|c|c|}
\hline & 2007. & 2008. & 2009. & 2010. & 2011. & 2012. \\
\hline Prosjek EU 27 & $-0,9$ & $-2,4$ & $-6,9$ & $-6,5$ & $-4,4$ & $-4,0$ \\
\hline Španjolska & $\mathrm{I}, 9$ & $-4,5$ & $-\mathrm{II}, 2$ & $-9,7$ & $-9,4$ & $-\mathrm{IO}, 6$ \\
\hline Grčka & $-6,5$ & $-9,8$ & $-15,6$ & $-\mathrm{IO}, 7$ & $-9,5$ & $-\mathrm{IO}, \mathrm{O}$ \\
\hline Irska & $\mathrm{O}, \mathrm{I}$ & $-7,4$ & $-13,9$ & $-30,8$ & $-13,4$ & $-7,6$ \\
\hline Portugal & $-3, \mathrm{I}$ & $-3,6$ & $-\mathrm{IO}, 2$ & $-9,8$ & $-4,4$ & $-6,4$ \\
\hline Cipar & 3,5 & 0,9 & $-6, \mathrm{I}$ & $-5,3$ & $-6,3$ & $-6,3$ \\
\hline Velika Britanija & $-2,8$ & $-5, \mathrm{I}$ & $-\mathrm{II}, 5$ & $-\mathrm{IO}, 2$ & $-7,8$ & $-6,3$ \\
\hline Francuska & $-2,7$ & $-3,3$ & $-7,5$ & $-7, \mathrm{I}$ & $-5,3$ & $-4,8$ \\
\hline Češka & $-0,7$ & $-2,2$ & $-5,8$ & $-4,8$ & $-3,3$ & $-4,4$ \\
\hline Slovačka & $-\mathrm{I}, 8$ & $-2, I$ & $-8,0$ & $-7,7$ & $-5, \mathrm{I}$ & $-4,3$ \\
\hline Nizozemska & 0,2 & 0,5 & $-5,6$ & $-5, \mathrm{I}$ & $-4,5$ & $-4, \mathrm{I}$ \\
\hline Danska & 4,8 & 3,2 & $-2,7$ & $-2,5$ & $-\mathrm{I}, 8$ & $-4,0$ \\
\hline Slovenija & $\mathrm{O}, \mathrm{O}$ & $-\mathrm{I}, 9$ & $-6,2$ & $-5,9$ & $-6,4$ & $-4,0$ \\
\hline Belgija & $-\mathrm{O}, \mathrm{I}$ & $-I, O$ & $-5,6$ & $-3,8$ & $-3,7$ & $-3,9$ \\
\hline Poljska & $-\mathrm{I}, 9$ & $-3,7$ & $-7,4$ & $-7,9$ & $-5,0$ & $-3,9$ \\
\hline Malta & $-2,3$ & $-4,6$ & $-3,7$ & $-3,6$ & $-2,8$ & $-3,3$ \\
\hline Litva & $-\mathrm{I}, \mathrm{O}$ & $-3,3$ & $-9,4$ & $-7,2$ & $-5,5$ & $-3,2$ \\
\hline Italija & $-1,6$ & $-2,7$ & $-5,5$ & $-4,5$ & $-3,8$ & $-3,0$ \\
\hline Rumunjska & $-2,9$ & $-5,7$ & $-9,0$ & $-6,8$ & $-5,6$ & $-2,9$ \\
\hline Austrija & $-0,9$ & $-0,9$ & $-4, I$ & $-4,5$ & $-2,5$ & $-2,5$ \\
\hline Finska & 5,3 & 4,4 & $-2,5$ & $-2,5$ & $-0,8$ & $-\mathrm{I}, 9$ \\
\hline Mađarska & $-5, I$ & $-3,7$ & $-4,6$ & $-4,3$ & 4,3 & $-\mathrm{I}, 9$ \\
\hline Latvija & $-0,4$ & $-4,2$ & $-9,8$ & $-8, \mathrm{I}$ & $-3,6$ & $-\mathrm{I}, 2$ \\
\hline Bugarska & $\mathrm{I}, 2$ & $\mathrm{I}, 7$ & $-4,3$ & $-3, \mathrm{I}$ & $-2,0$ & $-0,8$ \\
\hline Luxembourg & 3,7 & 3,2 & $-0,8$ & $-0,9$ & $-0,2$ & $-0,8$ \\
\hline Švedska & 3,6 & 2,2 & $-0,7$ & 0,3 & 0,2 & $-0,5$ \\
\hline Estonija & 2,4 & $-2,9$ & $-2,0$ & 0,2 & $\mathrm{I}, 2$ & $-0,3$ \\
\hline Njemačka & 0,2 & $-\mathrm{O}, \mathrm{I}$ & $-3, I$ & $-4, \mathrm{I}$ & $-0,8$ & 0,2 \\
\hline
\end{tabular}

Izvor: Eurostat, 2013.

Tablica 2.

Javni dug (konsolidirani) sektora opće države od 2007. do 20I2. (u \% BDP-a)

\begin{tabular}{|c|c|c|c|c|c|c|}
\hline & 2007. & 2008. & 2009. & 2010. & 2011. & 2012. \\
\hline Prosjek EU 27 & 59,0 & 62,3 & 74,6 & 80,0 & 82,5 & 85,3 \\
\hline Grčka & 107,4 & III, 9 & 129,7 & $\mathrm{I} 48,3$ & $\mathrm{I} 7 \mathrm{O}, 3$ & 156,9 \\
\hline Italija & IO3,3 & IO6,I & $\mathrm{II} 6,4$ & IIg,3 & $\mathrm{I} 2 \mathrm{O}, 8$ & $\mathrm{I} 27, \mathrm{O}$ \\
\hline Portugal & 68,4 & $7 \mathrm{I}, 7$ & 83,7 & 94,0 & IO8,3 & $\mathrm{I} 23,6$ \\
\hline Irska & $25, \mathrm{I}$ & 44,5 & 64,8 & $92, \mathrm{I}$ & IO6,4 & $\mathrm{II} 7,6$ \\
\hline Belgija & 84,0 & 89,2 & 95,7 & 95,5 & 97,8 & 99,6 \\
\hline Francuska & 64,2 & 68,2 & 79,2 & 82,4 & 85,8 & 90,2 \\
\hline Velika Britanija & 44,2 & 52,7 & 67,8 & 79,4 & 85,5 & 90,0 \\
\hline Cipar & 58,8 & 48,9 & 58,5 & 61,3 & $7 \mathrm{I}, \mathrm{I}$ & 85,8 \\
\hline Španjolska & 36,3 & 40,2 & 53,9 & $6 \mathrm{I}, 5$ & 69,3 & 84,2 \\
\hline Njemačka & 65,2 & 66,8 & 74,5 & 82,4 & 80,4 & $8 \mathrm{I}, 9$ \\
\hline Mađarska & 67,0 & 73,0 & 79,8 & $8 \mathrm{I}, 8$ & $8 \mathrm{I}, 4$ & 79,2 \\
\hline Austrija & 60,2 & 63,8 & 69,2 & 72,0 & 72,5 & 73,4 \\
\hline Malta & 60,7 & 60,9 & 66,4 & 67,4 & 70,3 & $72, \mathrm{I}$ \\
\hline Nizozemska & 45,3 & 58,5 & 60,8 & 63,1 & 65,5 & 71,2 \\
\hline Poljska & $45, \mathrm{O}$ & $47, I$ & 50,9 & 54,8 & 56,2 & 55,6 \\
\hline
\end{tabular}

6 NEWSLETTER 8I | A. BAJO I D. GALINEC | Deset istina o proceduri za države s prekomjernim... | Institut za javne financije 


\begin{tabular}{|c|c|c|c|c|c|c|}
\hline Slovenija & $23, \mathrm{I}$ & 22,0 & 35,0 & 38,6 & 46,9 & $54, \mathrm{I}$ \\
\hline Finska & 35,2 & 33,9 & 43,5 & 48,6 & 49,0 & 53,0 \\
\hline Slovačka & 29,6 & 27,9 & 35,6 & $4 \mathrm{I}, \mathrm{O}$ & 43,3 & $52, \mathrm{I}$ \\
\hline Češka & 27,9 & 28,7 & 34,2 & 37,8 & 40,8 & 45,8 \\
\hline Danska & $27, \mathrm{I}$ & 33,4 & 40,7 & 42,7 & 46,4 & 45,8 \\
\hline Latvija & 9,0 & 19,8 & 36,9 & 44,4 & $4 \mathrm{I}, 9$ & 40,7 \\
\hline Litva & $\mathrm{I} 6,8$ & $\mathrm{I} 5,5$ & 29,3 & 37,9 & 38,5 & 40,7 \\
\hline Švedska & 40,2 & 38,8 & 42,6 & 39,4 & 38,4 & 38,2 \\
\hline Rumunjska & $\mathrm{I} 2,8$ & $\mathrm{I} 3,4$ & 23,6 & 30,5 & 34,7 & 37,8 \\
\hline Luxembourg & 6,7 & $\mathrm{I} 4,4$ & 15,3 & 19,2 & 18,3 & 20,8 \\
\hline Bugarska & $\mathrm{I} 7,2$ & $\mathrm{I} 3,7$ & I4, 6 & 16,2 & 16,3 & $\mathrm{I} 8,5$ \\
\hline Estonija & 3,7 & 4,5 & 7,2 & 6,7 & 6,2 & IO,I \\
\hline
\end{tabular}

Izvor: Eurostat, 2013 .

\section{Tablica 3.}

Proračunski deficit i dug opće države u Hrvatskoj od 2005. do 20I3. (u \% BDP-a)

\begin{tabular}{|c|c|c|c|c|c|c|c|c|c|}
\hline & 2005 & 2006. & 2007. & 2008. & 2009. & 2010. & 2011. & 2012. & 2013.* \\
\hline Proračunski deficit opće države* & $-2,4$ & $-\mathrm{I}, 5$ & $-\mathrm{I}, \mathrm{O}$ & $-0,8$ & $-3,3$ & $-4,5$ & $-4,5$ & $-3,8$ & $-3,6$ \\
\hline Dug opće države & 38,2 & 35,4 & 32,9 & 29,3 & 35,8 & 42,2 & 47,2 & 53,7 & 53,5 \\
\hline Jamstva & 4,7 & 4,9 & 5,5 & 9,9 & II,7 & $\mathrm{I} 3,7$ & $\mathrm{I} 4, \mathrm{I}$ & II,7 & II,7 \\
\hline Dug HBOR-a & 2,7 & 2,6 & 3,0 & $3, \mathrm{I}$ & 3,8 & 4,4 & 4,0 & 4,9 & 4,9 \\
\hline Dug opće države + jamstva + dug HBOR-a & 45,6 & 42,9 & $4 \mathrm{I}, 4$ & 42,3 & $5 \mathrm{I}, 3$ & 60,3 & 65,3 & 70,3 & 70,I \\
\hline
\end{tabular}

*Podaci za proračunski deficit za 20I3. su planirane vrijednosti, a podaci za dug opće države, jamstva i dug HBOR-a su stanje 30.6.20I3. Izvor: HNB i Vlada RH podaci za proračunski deficit, MF podaci za dug opće države, jamstva i dug HBOR-a. 